\title{
Pemberdayaan Koperasi Sebagai Alternatif Pembiayaan Masyarakat Desa Kare Menuju Desa Mandiri
}

\author{
Novy Rachma Herawati ${ }^{1}$, Andik Susanto ${ }^{2}$ \\ ${ }^{\text {I} F a k u l t a s ~ E k o n o m i, ~ U n i v e r s i t a s ~ M e r d e k a ~ M a d i u n, ~ J l . ~ S e r a y u ~ N o .79, ~ M a d i u n, ~} 63133$ \\ E-mail: novy@unmer-madiun.ac.id \\ ${ }^{2}$ Fakultas Ekonomi, Universitas Merdeka Madiun, Jl. Serayu No.79, Madiun, 63133 \\ E-mail: andiksusanto@unmer-madiun.ac.id
}

\begin{abstract}
Cooperatives according to Law No. 25 of 1992 concerning Business Entities consisting of people or Cooperative Legal Entities by basing their activities based on Cooperative principles involved in the economic field based on family principles. There are various types of cooperatives in Indonesia, as well as cooperatives in Kare Village, Kare District, Madiun Regency, which are meant by Milk Cooperatives, KUD (Village Cooperative Units), Kopwan (Women's Cooperatives), etc. The methods used in this service are lectures, training and also mentoring. The objectives approved by this service are: a) The DesaKare community discusses the importance of cooperatives or becoming members of cooperatives related to community access can cope, $b$ ) Communities understand the process of building cooperatives and find out what should be done on cooperatives, this is a provision for the community to study cooperatives, c). Cooperative problems that have been dealt with so far, this is caused by the existence of information and assistance carried out continuously in assisting cooperatives that have difficulties, d) Growing public awareness of access that requires funds from banks in this strict financing and maintenance either in collateral or filling in Monitoring by Bank Indonesia (BI), e). The community becomes educated in this case is in choosing the management of the cooperative so that cooperative problems can be minimized, ff). Revive the spirit of mutual cooperation and help each other in the community through cooperative assistance and also foster enthusiasm in deliberation in decision making.
\end{abstract}

Keywords—: Cooperatives; Village Communities; Financing.

\section{PENDAHULUAN}

Koperasi menurut UU No.25 Tahun 1992 dijelaskan sebagai Badan Usaha yang beranggotakan orang-seorang atau Badan Hukum Koperasi dengan melandaskan kegiatannya berdasarkan prinsip Koperasi sekaligus sebagai gerakan ekonomi rakyat yang berdasar atas asas kekeluargaan. Pada prinsipnya koperasi didirikan lebih dari 1 (satu) orang, untuk koperasi primer syarat pendirian adalah 20 (dua puluh) orang. Koperasi tidak dapat dimiliki oleh satu orang melainkan merupakan kumpulan dari beberapa orang yang memiliki keinginan dan juga kepentingan yang sama, yaitu menyejahterakan anggotanya. Pertanyaan yang mungkin akan sangat relevan ditanyakan adalah apakah masih sangat memungkinkan koperasi bisa hidup di Era Milineal seperti saat ini ataukah sebenarnya koperasi mulai banyak ditinggalkan karena harus mengumpulkan orang banyak, segala keputusan harus musyawarah dan tentunya mungkin bagi sebagian atau banyak orang itu akan merepotkan.

Era Milineal merupakan era dimana kemajuan tekhnologi menguasai berbagai macam kehidupan sehari-hari, dimana semuanya tidak terlepas dari penggunaan tekhnologi, bahkansekarang banyak bermunculan uang elektronik yang hampir dimiliki oleh semua perbankan, maupun akses kemudahan lainnya yang ditawarkan oleh berbagai macam industri keuangan atau lembaga keuangan. Tetapi yang menjadi pertanyaan adalah tidak semua orang dapat mengaksesnya, bagaimana dengan masyarakat desa yang tidak memiliki kemampuan ekonomi secara baik, padahal akses pembiayaan di perbankan mensyaratkan banyak kelengkapan administrasi dan tentunya lebih rumit dibandingkan dengan koperasi. Negara-negara maju seperti Amerika, Singapura, dan Jepang hampir semua masyarakatnya tergabung dalam koperasi, mereka memiliki kemampuan dalam mengelola perekonomiannya sendiri. Jepang bahkan hampir $90 \%$ masyarakatnya tergabung dalam koperasi. Berbeda dengan negara lain, di Indonesia koperasi banyak yang tidak tumbuh dengan baik, bahkan banyak masyarakat yang tidak tergabung dalam koperasi, secara kuantitas jumlah koperasi sangat banyak tetapi tidak diimbangi dengan kualitas yang ada. Berdasarkan data Kemenkop UKM tahun 2017 jumlah koperasi di Indonesia sebanyak 209.000 koperasi. Dari jumlah tersebut 147.000 koperasi yang aktif dan yang tidak aktif sebanyak 62.000 koperasi (www.ekonomi.kompas.com, diakses 1 September 2018).

Koperasi apabila dimanfaatkan dengan baik tentunya akan memberikan dampak yang positif bagi masyarakatnya, seperti koperasi yang berada di Desa Kare, Kecamatan Kare, Kabupaten Madiun. Koperasi di desa ini ada bermacam-macam, mulai dari Koperasi Susu (didirikan oleh peternak susu), KUD (Koperasi Unit Desa), Kopwan (Koperasi Wanita) dan yang akan didirikan pada tahun 2018 ini adalah Koperasi yang beranggotakan Gabungan Kelompok Tani (GAPOKTAN). Desa Kare terletak di wilayah Kecamatan Kare, Kabupaten Madiun yang merupakan desa yang berada di wilayah lereng wilis, dimana sebagian besar mata pencaharian penduduk adalah sebagai petani dan pekebun ( $\pm 65 \%$ dari jumlah penduduk). Banyak masyarakat yang menggantungkan kehidupan sehari-hari dari hasil sawah yaitu padi, hasil perkebunan seperti cengkeh, kopi, dll. 
Website : http://dayamas.unmermadiun.ac.id/index.php/dayamas

Letaknya yang jauh dari kota dan berada di lereng gunung menjadikan masyarakat di wilayah tersebut minim terhadap akses informasi seperti akses terhadap pembiayaan keuangan, seperti koperasi maupun perbankan.

Terkait dengan koperasi banyak permasalahan yang dihadapi oleh masyarakat Desa Kare diantaranya adalah banyak masyarakat yang tidak tahu manfaat dari koperasi, sehingga banyak yang tidak mau tergabung dalam koperasi karena selama ini memang masyarakat belum tahu manfaat yang bisa diperoleh. Terdapat koperasi di Desa Kare yang bermasalah, salah satunya adalah KUD (Koperasi Unit Desa) dimana selama ini diindikasi banyak dimanfaatkan secara pribadi oleh pengurusnya dan anggota koperasinya tidak mendapatkan manfaat apa-apa seperti SHU (Sisa Hasil Usaha) yang tidak dibagikan kepada anggotanya. Permasalahan lainnya adalah masyarakat tidak mengetahui cara mendirikan koperasi dan bagaimana proses setelahnya setelah koperasi didirikan.

\section{TARGET \& LUARAN}

Pengabdian Kepada Masyarakat ini diharapkan:

1. Memberikan wawasan atau pengetahuan kepada masyarakat Desa Kare, Kecamatan Kare, Kabupaten Madiun tentang manfaat yang diperoleh dari berkoperasi atau menjadi anggota koperasi.

2. Memberikan pendampingan proses pendirian koperasi dan juga proses atau tahap yang dilakukan setelah koperasi terbentuk.

3. Membantu memecahkan permasalahan yang ada dalam KUD (Koperasi Unit Desa) sehingga anggota mendapatkan manfaat keanggotaannya sebagai anggota koperasi.

4. Artikel Ilmiah

\section{III.MANFAAT \& DAMPAK SOSIAL}

Manfaat dan dampak sosial yang dilakukan terhadap masyarakat Desa Kare dalam memberdayakan koperasi, diantaranya adalah sebagai berikut:

1. Masyarakat Desa Kare memahami pentingnya berkoperasi atau menjadi anggota koperasi sehingga permasalahan masyarakat terkait dengan akses pembiayaan dapat teratasi.

2. Masyarakat mengetahui proses mendirikan koperasi dan mengetahui apa yang harus dilakukan setelah koperasi berdiri, hal ini sebagai bekal kepada masyarakat untuk belajar berkoperasi.

3. Permasalahan-permasalahankoperasi yang selama ini dihadapi dapatdiselesaikan, hal ini dikarenakan adanya akses informasi dan pendampinganyang dilakukan secara terus-menerus dalam membantu koperasiyang bermasalah.

4. Tumbuhnya kesadaran masyarakat akan akses pembiayaan selain perbankan hal ini dikarenakan perbankan memiliki persayaratan yang lebihrumit dalam pembiayaan dan adanya pengawasan yang ketat baik dalam agunan atau jaminan maupun dalam pembayaran karena diawasi oleh Bank Indonesia (BI).

5. Masyarakat menjadi terdidik dalam hal ini adalah dalam memilih pengurus koperasi sehingga kedepannya masalah koperasi bisa diminimalisir.

6. Menumbuhkan kembali semangat bergotong royong dan saling membantu di masyarakat melalui keanggotaan koperasi dan juga menumbuhkan semangat dalam bermusyawarah dalam pengambilan keputusan.

\section{IV.METODE PELAKSANAAN}

Sasaran kegiatan dalam pengabdian ini adalah Masyarakat Desa Kare baik yang sudah tergabung menjadi anggota koperasi maupun yang belum bergabung dengan koperasi. Adapun metode pendekatan yang ditawarkan untuk menyelesaikan persoalan yang ada adalah dengan melakukan pelatihan dan juga pendampingan secara terus-menerus dengan kegiatan sebagai berikut:

1. Melakukan mapping (pemetaan) terhadap jenis koperasi yang ada di Desa Kare, Kecamatan Kare, Kabupaten Madiun.

2. Melakukan pendataan terkait dengan pengurus, pengawas dan jumlah anggota yang tergabung dalam koperasi dan permasalahan dari masing-masingkoperasi.

3. Mengurus administrasi dan perizinan terkait dengan surat-menyuratbaikkepada pihak desa maupun ke koperasi yang akan dilakukanpelatihan maupun pendampingan.

4. Penyusunan jadwal kegiatan dan melakukan kesepakatan dengan pihak-pihak yang akan diberikan pelatihan dan pendampingan kegiatan.

5. Pembuatan materi pelatihan sesuai dengan permasalahan yang dihadapi oleh setiap koperasi.

\section{HASIL DAN PEMBAHASAN}

Hasil daripelatihandanpendampinganpada Masyarakat DesaKareadalahsebagaiberikut:

1. Metode ceramah.

Pematerilebih mudah dalam menggaliinformasisecaradetail terhadap permasalahan yang dihadapi, dalam pertemuan awal tersebut dihadiri oleh para pengurus, pengawas dan juga para anggota.Terkait dengan koperasi yang akan awal dibentuk maka perlu dihadiri paling tidak adalah 20 (dua puluh) orang yang dalam hal ini adalah anggota GAPOKTAN (Gabungan Kelompok Tani). 
Website : http://dayamas.unmermadiun.ac.id/index.php/dayamas

2. Melakukan pelatihan.

Pelatihan yang telahdilakukan adalah memberikan solusi terhadap permasalahanyang dihadapi di masing-masing koperasi, artinya karena setiap masalah yang dihadapi berbeda otomatis metode pelatihan yang dilakukan akan berbeda. Dalam metode ini menggunakan modelFGD (Focus Group Disscussion) sehingga lebih memudahkan mendeteksi dalam memberikan materi dan juga saran serta solusi yang ditawarkan terkait dengan masalah yang ada.

3. Pendampingan secara terus-menerus.Pendampingan ini sangat penting karena untuk mengetahui sejauh mana solusi yang sudah ditawarkan akan diaplikasikan dalam kegiatan berkoperasi.Permasalahan yang sering terjadi di lapangan adalah tidak adanya pendampingan secara berkesinambungan sehingga solusi yangditawarkan jarang dipakai atau digunakan dalam jangka waktu yang lama, artinya hanya semangat di awal saja tetapi selanjutnya kesalahan yang sudah dilakukan diulangi lagi terutama oleh pengurus dan pengawas koperasi.

4. Partisipasi Mitra dalam pelaksanaan kegiatan inidiantaranya adalah memilikidampaksebagai berikut:

5. Pemberian informasi secara detail terkait kendala maupun permasalahan yang dihadapi dikoperasi.

6. Keterbukaan kepada pemateri tentang dokumen maupun Laporan Keuanganataupun hal-hal lain yang bersifat fisik sehingga pemateri mudahdalam memberikan solusi yang akan diberikan.

7. Berperan aktif mengikuti pelatihan maupun instruksi yang diberikanoleh pemateri hal ini disebabkan karena dalam koperasi melibatkan banyak orang artinya bisa jadi dalam satu koperasi memiliki jumlah anggota yang banyak dan jumlah anggota yang sedikit, tentunya hal itu membutuhkan perlakuan yang berbeda bahkan di setiap jenis koperasi akan memiliki metode pendekatan yang berbeda pula.

8. Adanya komitmen antara pihak koperasi dan pemateri bahwa pelatihan dan pendampingan yang dilakukan tidak hanya dilakukanpada saat itu tetapi dilakukan dalam jangka waktu yang lama atau berkesinambungan sehingga bila terjadi permasalahan yang sama sudah mengetahui langkah apa yang harus dilakukan.

\section{VI.KESIMPULAN}

Dengan adanya pendampingan dan pelatihan yang dilakukanpadaMasyarakat Desa Kare sehingga permasalahan masyarakat terkait dengan akses pembiayaan dapat teratasi, Masyarakat mengetahui proses mendirikan koperasi dan mengetahui apa yang harus dilakukan setelah koperasi berdiri, hal ini sebagai bekal kepada masyarakat untuk belajar berkoperasi.

Tumbuhnya kesadaran masyarakat akan akses pembiayaan selain perbankan, hal ini dikarenakan perbankan memiliki persayaratan yang lebih rumit dalam pembiayaan dan adanya pengawasan yang ketat baik dalam agunan atau jaminan maupun dalam pembayaran karena diawasi oleh Bank Indonesia (BI). Selainitumasyarakat menjadi terdidik dalam hal ini adalah dalam memilih pengurus koperasisehingga kedepannya masalah koperasi bisa diminimalisir, menumbuhkan kembali semangat bergotong royong dan saling membantu di masyarakat melalui keanggotaan koperasi dan juga menumbuhkan semangat dalam bermusyawarah dalam pengambilan keputusan.

\section{DAFTAR PUSTAKA}

Peraturan Perundang-Undangan No. 25 Tahun 1992 tentang perkoperasian. Jakarta, Kementrian Koperasi dan Usaha Kecil dan Menengah Republik Indonesia. Bubarkan Koperasi yang Tidak Aktif https://ekonomi.kompas.com/read/2017/02/21/090546726/pemerintah.gencar.bubarkan.koperasi.yang.tidak.aktif. 